\title{
16 Days of Activism for No Violence Against Women and Children
}

\author{
Hawabibi Laher
}

To mark the beginning of the 16 Days of Activism for No Violence Against Women and Children (25 November-10 December) the University of South Africa's Institute for Social and Health Sciences (Unisa-ISHS) held a dialogue at the Don Mateman Hall in Eldorado Park. The convener of the event was Royal Lekoba. Over 90 community members participated in the event. Speakers included Inspector Basset of the Victim Empowerment Centre of the South African Police Services (SAPS) in Eldorado Park. She painted a picture of violence against women and children in the area. Basset addressed various problems affecting the Eldorado Park area, in particular domestic violence which is a major concern. From January 2008 until November 2008, 69 cases of assault resulting in serious injuries were reported for the area. Basset also stated that 537 applications for protection orders had been filed for the period. Abandoned children, substance abuse as well as school-related gangsterism were highlighted as other key issues affecting the youth in the area.

Sima Vallaph of the Nisaa Institute for Women's Development (NISAA) provided an insight into the work and support that NISAA as an organisation provides for women. The organisation offers shelter to women affected by abuse and also provides self-empowerment workshops for women to assist them to gain independence.

Lisa Vetten of the Tshwaranang Legal Advocacy Centre presented an overview of violence against women and children on a national level. Vetten stressed that preventing violence cannot be accomplished exclusively by the SAPS; instead it is a developmental issue that should be addressed by all sectors as it is also a health and economic problem. Vetten elaborated on the prevalence of sexual violence and in particular rape. SAPS rape statistics for the 2006/2007 period 
indicated an alarming 52617 reported cases, $42.7 \%$ of which were reported by children.

Municipal Councillors for the area, Norman Duncan and Patience Peterson, addressed the need to empower women. Their sentiments echoed those of previous speakers in that the problem of violence against women and children in the Eldorado Park area is rife and needs to be addressed. The dialogue allowed for community members to voice their concerns and take a stand against violence.

In supporting the annual national 16 Days of Activism for No Violence Against Women and Children, the Unisa-ISHS has taken the initiative in attempting to foster dialogue and awareness concerning issues of violence against women and children in its areas of operation. In the face of the high levels of violence and crime in South Africa the author believes that the initiative is especially important and should be continued. 